\title{
Iran's Multi-ethnic Mosaic: A 23-Year Perspective
}

\author{
Mahdi Majbouri ${ }^{1}$ (D) $\cdot$ Sanaz Fesharaki
}

Accepted: 17 November 2017/Published online: 24 November 2017

(C) UNU-WIDER 2017, corrected publication February 2019

\begin{abstract}
In this study, we embark on measuring inequality in Iran. We compute three measures of group-based inequality (Group-weighted Coefficient of Variation, Groupweighted Gini, and Group-weighted Theil) for the following outcomes: education, assets, income, and expenditure per capita. The groups are defined based on gender, ethnicity/ language (Persian, Azeri, and other ethnic minorities), and region (urban versus rural and capital city versus other places) using 23 years of annual Household Expenditure and Income Surveys from 1990 through 2012. Inequality between groups based on religion (Muslim, non-Muslim), citizenship (Iranian, non-Iranian) are also studied using the 2006 census. Our analysis of the trend of horizontal inequality reveals substantial reduction in between-group inequalities over the 1990-2012 period. Yet, gender based income inequality remains high. The implications and underlying reasons for these results are discussed.
\end{abstract}

Keywords Group-based inequality · Inequality among ethnicities · Gender inequality $\cdot$ Regional inequality · Inequality measures · Iran

The original version of this article was revised due to a retrospective Open Access order.

Mahdi Majbouri

mmajbouri@babson.edu

Sanaz Fesharaki

sanaz@vt.edu

1 Economics Division, Babson College, 231 Forest St, Wellesley, MA 02457, USA

2 Economics Department, Virginia Tech, 3016 Pamplin Hall, 880 West Campus Drive, Blacksburg, VA 24061, USA 


\section{Introduction}

Studying inequality has been as old as the economic science itself. But particularly, since the financial crisis of 2008, there has been a resurgence of interest in it both in the eyes of the public, globally, and in the academic circles. The 'Occupy Wall Street' and the '99 percent' movements in the United States (US) and the success of the left in some European countries $^{1}$ as well as the publication of The Capital in the 21 st Century by Thomas Piketty (2013) and its popularity are just a few examples of this resurgence. But most of the interest is focused on vertical inequality, inequality among the rich and the poor at the country level, and less attention has been devoted to horizontal inequality, inequality among groups in a society.

Horizontal inequality should be particularly important for policy makers as it can be a predictor of political instability and development. For example, Stewart and Langer (2008) and Stewart (2000) show that inequalities among groups (ethnic, religious, etc.) can predict political instability. This is particularly important in countries with ethnic or religious diversity, such as the countries in the Middle East and North Africa (MENA) region. ${ }^{2}$

Iran is an interesting example of ethnic diversity. According to Alesina et al. (2003), ethnic fractionalization in Iran in 1989 has a score of .6684, while language fractionalization has a score of .7462 , and religious fractionalization $0.1152 .^{3}$ The larger these measures are, the more diversity there is. The averages for these three measures in the MENA region are 0.453, 0.330, and 0.346, respectively (Alesina et al. 2003, Table 3). Therefore, Iran is ethnically and linguistically more diverse than an average Middle Eastern country (but religiously less diverse.) At the same time, the Middle East has the largest of these fractionalization measures in the world after sub-Saharan Africa (SSA).

Fearon (2003) constructs an index of cultural fractionalization using structural distance between languages as a proxy for cultural distance between groups. Iran's cultural fractionalization is estimated to be 0.542 , which is the second highest in the MENA region. It is interesting that despite the fact that Iran is a highly diverse country, it has not experienced ethnic conflict the way some other countries have. This could be because the ethnic groups in Iran are well-integrated, and group-based inequalities have been low or decreasing over time. Therefore, studying horizontal inequalities in Iran and having a better picture of them is interesting and important for researchers and policy makers alike.

Ethnic conflict is not the only unfavourable consequence of horizontal inequality. Even in the absence of conflicts, between-group inequality affects the wellbeing of individuals within groups because the relative wellbeing of a group is an important factor of individual wellbeing. Moreover, between-group inequalities reduce growth potential (Stewart 2005). Stewart also emphasizes the critical importance of horizontal inequality for development and calls it a 'neglected dimension of development'. Current development analyses and policies are focused on improving individual's welfare, neglecting the correlation between individual's and group's wellbeing. But, when being a group member is resulting in being discriminated or disadvantaged, improvement in individual welfare is conditioned on improvement in the group welfare. For instance,

\footnotetext{
${ }^{1}$ Such as the Podemos in Spain and Syriza (the coalition of the radical left) in Greece.

2 The region has been in turmoil recently and ethnic divisions were in the centre of the conflict.

${ }^{3}$ Fractionalization is the most widely used measure of diversity. It is the probability that two individuals who are randomly chosen from the society belong to different groups.
} 
van Staveren and Pervaiz (2017) suggest that it is social exclusion rather than diversity per se that affects economic outcomes. ${ }^{4}$

There have been studies on poverty, vertical inequality, and inequality of opportunity in Iran. But very little has been done on horizontal inequality. Assadzadeh and Paul (2004) examine the changes in the extent of poverty in Iran between 1983 and 1993. They show that both rural and urban poverty increased in the first half of this period during the IranIraq war, an economic recession, and fall of oil revenues, but they decreased after the war, in the reconstruction period. Salehi-Isfahani (2009) studies the trends in poverty and inequality of expenditure in the 1984-2004 period. He finds that poverty decreased in the long run substantially compared to the pre-revolution era, while the reduction in inequality of expenditure was negligible in this period. Salehi-Isfahani and Majbouri (2013) use a panel data and find substantial income mobility in Iran during 1992-1995 period. They also measure transient and chronic poverty and their correlates. ${ }^{5}$ Salehi-Isfahani et al. (2014) study inequality of opportunity in Iran, Egypt, and Turkey, and find that inequality in educational achievements is mostly a result of the inequality of opportunities. Although the literature provides a picture of vertical inequality and poverty, it is focused on individuals and households. Hence, there is very little known about group-based inequalities in contemporary Iran.

To the best of our knowledge, Aghajanian (1983) is the only study discussing inequality among ethnic groups in Iran. Using geographically distinct regions and provinces to identify ethnic communities, Aghajanian compares literacy rates, access to electricity and piped water, occupation in agricultural sector, urban residency, and poverty rate among Kurds, Azeris, Baluchs, and Persians in 1966 and 1976. The study concludes that even though the country had substantial economic growth due to booming oil prices, inequality among ethnic communities widened during this period. But this study is about four and five decades ago and it is silent on important socioeconomic outcomes, such as income, expenditure, and educational inequality.

This study is the first comprehensive research of group-based inequality in Iran after the revolution. It is distinguished from the previous work in three ways: first, extensive datasets that cover every year between 1990 and 2012 is used to build a comprehensive picture of variation in group-based inequalities across gender and ethnicity in this period. Moreover, we provide group-based inequalities across religion and citizenship for 2006. Second, a wide range of socioeconomic characteristics are examined, including attained years of education, asset index, individual income, and household per capita expenditure. ${ }^{6}$ Third, we verify the consistency of our grouping methodology by using a unique dataset, ${ }^{7}$ which includes the information of the ethnicity of an individual. In addition, we explain the impact of policies and macroeconomic shocks, inflation, and oil prices, on horizontal inequality trends.

The main ethnic groups in Iran are Persians, Azeris, Kurds, Lors, Arabs, Baluchs, Turkmans, Mazanis, and Gilaks. Persians and Azeris form over $70 \%$ of the population and other groups combined constitute less than 30\%. For this and other technical reasons further explained in Sect. 3.3, we study inequality among three main groups: Persians,

\footnotetext{
4 Another advantage of studying group-wise inequality measures is that some indices of horizontal inequality can be used to derive indices of vertical inequality (Jayaraj and Subramanian 2006).

5 They show that three groups are more likely to be chronically poor: people who live in urban areas, younger individuals, and those living in female headed families.

6 The groups and variables are discussed in detail in Sects. 3.3 and 4 respectively.

7 Socio-economic Characteristics of Households 1992.
} 
Azeris, and Others. Each ethnicity has their own language/dialect, and similar to some European countries such as Belgium, Luxembourg, and Switzerland, language groups match almost perfectly the ethnic groups. Therefore, studying ethnic groups is similar to studying language groups. Persian, however, is the official language and more than $90 \%$ of the population regardless of their ethnicity can speak it. Iran is more homogeneous in terms of religion: nearly $90 \%$ of Iranians associate themselves with the Shi'ite branch of Islam (the state religion) and about 10\% with various Sunni and Sufi branches of Islam. There are also Christian, Jewish, and Zoroastrian minorities (CIA 2013). Since they are small minorities, we include them together as non-Muslims. Therefore, for this and other technical reasons discussed in Sect. 3.3, we study Muslims and non-Muslims. Similarly, there is a migrant population in Iran mostly from Afghanistan. We split the data into Iranians and non-Iranians and study inequality among those. Following Stewart (2000), who argues that other dimensions such as region of residence can be a source of group formation, we also study inequality among regions (urban vs. rural and capital vs. other places).

The rest of the paper is organized as follows: the next section gives a brief but substantive overview of the economy of Iran and discusses vertical inequality. Section 3 explains the data and the way groups are defined. Sections 4 and 5 explain our results for the Household and Expenditure Surveys (HEIS) between 1990 and 2012 and the 2006 Census. Section 6 concludes.

\section{Iran's Economy and Society in Recent Decades}

Understanding the trends in inequality in Iran is not possible without an understanding of the Iranian economy and its trends. In this section, we look at the Iranian economy in the last five decades and discuss its main characteristics.

The contemporary economy of Iran is intertwined with oil and gas. Being the main export, oil has been a central player in the economy, beside the political events. It is and has been a fundamental source of revenue for the government and the main driver of

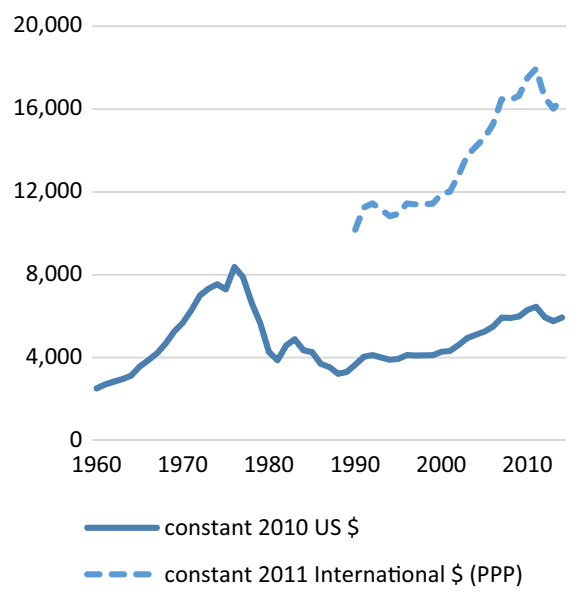

(a)

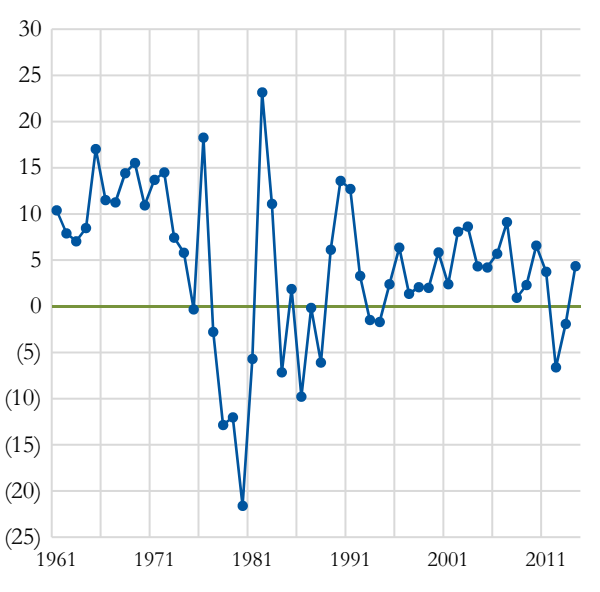

(b)

Fig. 1 GDP per capita and annual growth rate of GDP. a GDP per capita (in US\$ and PPP), b annual growth rate of GDP (per cent). Data source: World Bank National Account Data 
economic growth, and hence, the key source of funding development projects. The booms and busts in the economy have been strongly related to the global price of oil and the production and consumption of oil in Iran.

Figure 1a, b show GDP per capita and annual growth rate of GDP since 1960s. In the 1950 s and 1960s, when the price of oil was stable and low, the government devised development programmes and invested in infrastructure, particularly in urban areas. Electrification and piped water projects, along with road, school, and healthcare facility constructions in cities were main development projects. Moreover, the government pursued an import-substitution policy in this period, which gave birth to heavy and light industries and created economic growth, particularly in urban areas. Since the stock of capital was low in the country, growth rates were significant as the economic theory predicts (Fig. 1b). But with the sudden and unprecedented rise in the oil prices in the 1970s (Fig. 2a), particularly due to the Arab embargo and the creation of the Organization of the Petroleum Exporting Countries (OPEC), the government found itself with several times larger revenues than it usually had and hence, it became bolder in adopting short-sighted economic policies; despite the warnings from the economists. The new revenues were all spent on imports and large and ambitious but low-return projects. As a result, the domestic production shrank and the economy became highly dependable on oil prices. The economy continued to grow significantly, because of the rise in government expenditure. It was, however, very susceptible to a crash in oil prices, and the booms and busts of this market in general.

The price of oil is not necessarily a good measure of resources available to the government for two reasons: first, the production of oil has been changing over time, and second, population has been growing over time, shrinking the size of the revenue distributed to each person. Therefore, the annual revenue from exporting oil per capita is a better measure of the size of resources available to the government over time. This measure is calculated by taking the difference between annual production and consumption of oil,

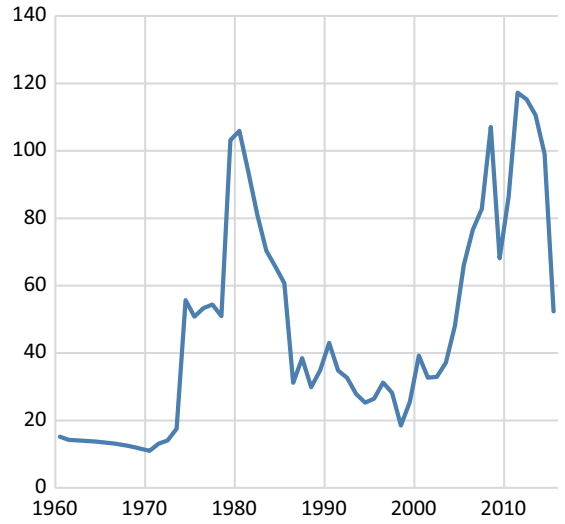

(a)

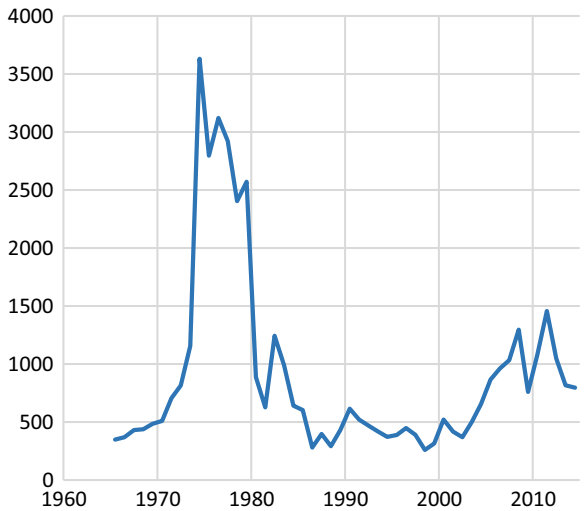

(b)

Fig. 2 Oil prices and annual oil revenue per capita, both in 2015 US\$. a Oil prices, West Texas Intermediate, b annual oil revenues per capita. Data source: BP Statistical Review of World Energy (http:// www.bp.com/en/global/corporate/energy-economics/statistical-review-of-world-energy/downloads.html (accessed on 30 July 2016). Annual oil revenues per capita were calculated by subtracting the annual domestic oil consumption from oil production and multiplying the result by the price of oil (West Texas Intermediate) and dividing it by the size of population in that year 

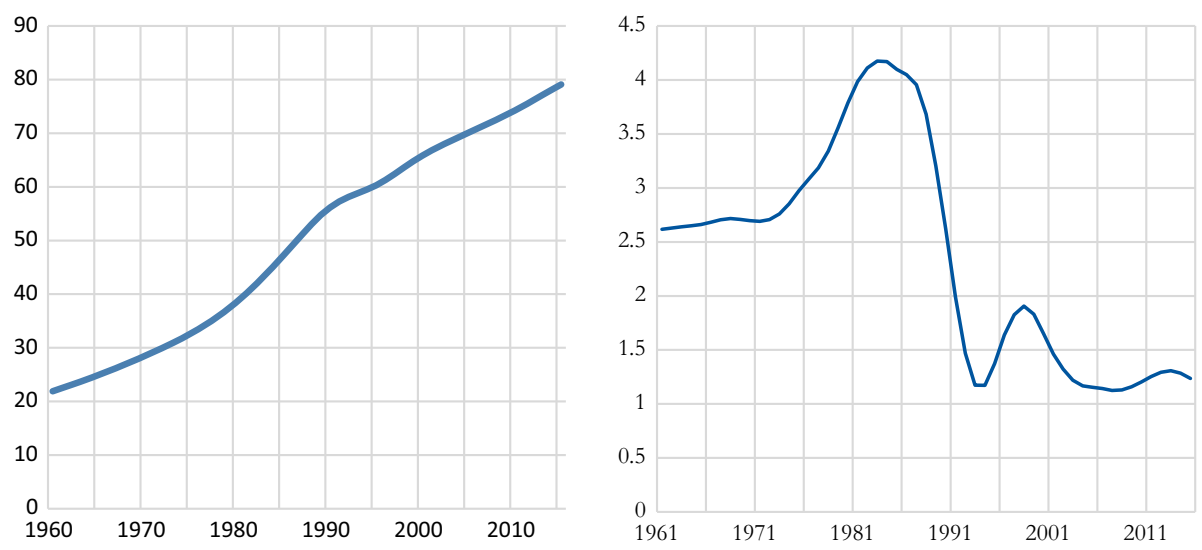

Fig. 3 Population (in millions) and population annual growth (\%). Data source: United Nations Population Division

multiplying it by the price of oil and dividing the result by the size of population. We subtract domestic consumption from total production, because domestic prices are highly subsidized in Iran and the revenue from domestic consumption is a small fraction of the revenue from oil export, and can be ignored. Figure $2 b$ reports this measure. As can be seen, this measure was by far at its peak in the 1970s. Even though in 2010, the price of oil reached and surpassed its levels in the late 1970s, the revenue per capita in 2010 was significantly smaller than in 1970s (see Fig. 2a, b). Therefore, one can see that the government in the 1970s was substantially more resourceful than any Iranian government in recent history. An interesting point about the revenue per capita is that its trend mimics that of GDP per capita nicely (compare Figs. 1a, 2b). This clearly shows how much the Iranian economy is dependent on oil.

With the political instability in the first year after the Islamic Revolution in 1979 as well as the Iran-Iraq war in 1980 along with the subsequent crash in oil markets, the country's economy was hit hard and the annual growth rates became low or negative (Fig. 1b). Moreover, the population growth in late 1970s and early 1980s (Fig. 3b) substantially contributed to the reduction of GDP per capita in the 1980s (Fig. 1a). A reconstruction period started after the war in 1989, while many infrastructure projects were designed and implemented which raised the growth rate to respectable two-digit levels. By 1993, however, government borrowing, particularly short-term debt, rose and oil prices declined below expectations. In late 1993, the government realized that it could not repay its debt. This led to the balance of payment crisis of 1994-95, which brought the economy to a recession and had consequences for households for the following few years. The government had to re-negotiate the terms of its debt and devalue the domestic currency, which raised the price of imports and inflation (Pesaran 2000). The inflation rose to about $50 \%$ in 1995, the highest the country had seen since the Second World War (Fig. 4). The price of oil was at low levels in the second half of the 1990s and the first half of the 2000s. This was a period of economic hardship, which led the government to take measured policies and carefully consider its expenditure and budget. With the continuous rise in oil prices between 2003 and 2008, when oil prices rose to the same levels as in the late 1970s (the highest levels seen since 1864), the new government started to spend more freely. Although the prices were at all-time high, the size of resources per person available to the 


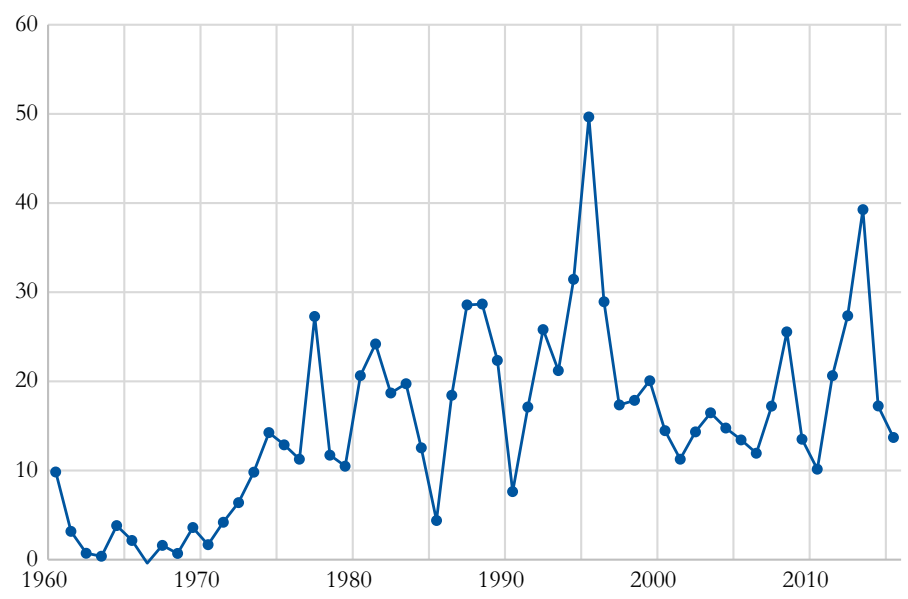

Fig. 4 Inflation (\%). Data source: International Monetary Fund

government was substantially lower than what was available to government in the 1970 s (see Fig. 2b). The economy grew but became more susceptible to the volatility in the oil market. ${ }^{8}$

In 2010, the sanctions on Iran became tighter and eventually, the price of oil collapsed in 2011. These events shrank the economy as depicted in Fig. 1.

\subsection{Expansion of Infrastructure}

One of the aims of the revolutionaries of the Islamic Revolution of 1979 was to serve the poor and the marginalized, particularly in rural areas. Therefore, the governments after the revolution made significant investments in expanding the infrastructure to rural areas, even during difficult times such as the Iran-Iraq war. Rural electrification projects in the 1980s and 1990s brought universal coverage to villages by 2000 (see Table 1). Similarly, almost all urban households had access to electricity in 1990. Many water projects in rural areas increased access to clean water to $84 \%$ in 2000 and $95 \%$ in 2012. By the 2000s, the main infrastructure projects at the rural level were about telecommunication and gas pipelines. The share of rural households which had access to piped gas increased to almost $50 \%$ in 2012 from just $4 \%$ in 2000. Ninety-two per cent of urban households had access to piped gas by 2012 . While $1 \%$ of rural households had a landline phone in 1990 , two-thirds were enjoying it by 2012. In 1990, none of the rural households had a cell phone; by $2012,81 \%$ of them had one.

The consequences of these changes in the economic wellbeing of rural population were substantial. The percentage of households having a kitchen and bath (two essential facilities that significantly improve wellbeing and health outcomes) increased from 39 and $22 \%$ in 1990 to $85 \%$ by 2012. Ownership of home appliances, such as stoves and fridges (two appliances that substantially increase household productivity), as well as televisions, became universal in rural areas by 2012. All these developments are reported in Table 1 for both rural and urban areas. In Sect. 4.2.2, we see how these developments reduced group-based inequality of asset ownership over time.

\footnotetext{
${ }^{8}$ See Hakimian (2014) for a discussion of macroeconomic performance in post-revolutionary Iran.
} 
Table 1 Percentage of households with access to infrastructure and ownership of facilities/ equipment in rural and urban areas. Source: Authors' calculations from Household Expenditure and Income Surveys of 1990 , 2000, and 2012

Fig. 5 Years of education attained across birth cohorts. Source: Authors' calculations

\begin{tabular}{|c|c|c|c|c|c|c|}
\hline & \multicolumn{3}{|l|}{ Rural } & \multicolumn{3}{|c|}{ Urban } \\
\hline & 1990 & 2000 & 2012 & 1990 & 2000 & 2012 \\
\hline Electricity & 73 & 96 & 100 & 99 & 100 & 100 \\
\hline Piped water & 63 & 84 & 95 & 96 & 99 & 100 \\
\hline Piped gas & 1 & 4 & 48 & 20 & 64 & 92 \\
\hline Landline phone & 1 & 23 & 65 & 28 & 64 & 85 \\
\hline Cellphone & - & 0 & 81 & - & 4 & 92 \\
\hline Kitchen & 39 & 64 & 85 & 81 & 90 & 97 \\
\hline Bath & 22 & 45 & 85 & 66 & 88 & 98 \\
\hline Stove & 59 & 83 & 96 & 88 & 96 & 99 \\
\hline Refrigerator & 54 & 86 & 98 & 92 & 97 & 100 \\
\hline Washer & 7 & 18 & 45 & 39 & 54 & 80 \\
\hline Vacuum cleaner & 3 & 16 & 59 & 26 & 58 & 88 \\
\hline TV & 46 & 81 & 96 & 87 & 95 & 99 \\
\hline Computer & - & 0 & 12 & - & 4 & 39 \\
\hline Car & 4 & 5 & 22 & 17 & 18 & 42 \\
\hline
\end{tabular}

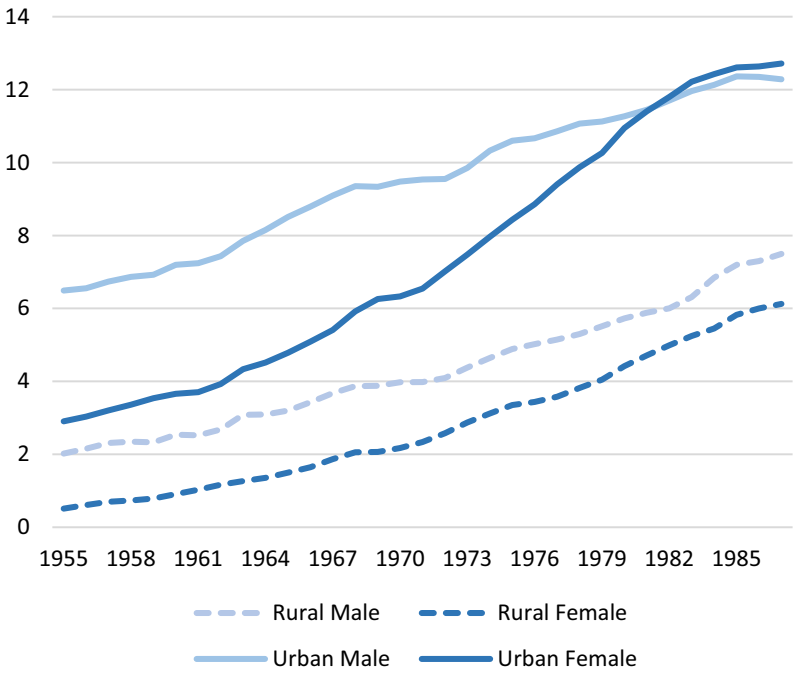

After the 1979 revolution, all private schools became public and access to (almost) free education increased significantly (Majbouri 2010). Moreover, a large-scale free adult literacy programme was implemented across the country. In addition, the post-revolution governments made significant investments in building educational facilities at all levels of education (primary, secondary, and even tertiary) across the country in small towns and villages, even during the Iran-Iraq war. In addition to schools, a private non-profit university was founded in 1983, which expanded rapidly across the country by building branches in large and small towns. As a result there was substantial increase in educational attainment, particularly for women. Figure 5 shows the increase in average years of education attained for men and women across birth cohorts. As can be seen from the figure, 
there is a continuous rise in educational attainment for each birth cohort. ${ }^{9}$ This rise was faster for urban women than urban men, so that the gender gap in years of education disappears in urban areas after the 1980 birth cohort. In rural areas, the gap still exists, but attainment rates were on the rise for both genders. The average female born in 1982 in rural areas has completed the 5-year primary education. Later cohorts have had even more education. We will discuss the implications of the expansion of educational infrastructure when we explain the trends in group-based inequality of educational attainment in Sect. 4.2.1.

The limitations for women to enter some fields in college were removed in the early 1990s. ${ }^{10}$ By mid-2000s, however, more than $60 \%$ of enrolled students in colleges were women. Therefore, by late 2000 s, quotas were put on female admission, so that no more than $60 \%$ of college students in each year be female.

Investments in educational facilities were complemented with similar projects on health infrastructure, particularly in rural areas. For example, health clinics were established across the country to offer preventative healthcare as well as prenatal care to the rural population. The clinics also provided basic treatments and offered subsidized birth control as well as advised women about fertility prevention methods. They are found to be one of the reasons behind the rapid reduction in fertility rates from 6.5 to 2.2 children per woman from 1985 and 2000s, respectively (Salehi-Isfahani et al. 2010; Abbasi-Shavazi et al. 2009).

Despite the increase in female education and decrease in fertility rates, female labour force participation remained at low levels (Fig. 6). It is a puzzle why the rates are low and why such significant changes in education and fertility had so little impact on it. ${ }^{11}$ But as we will see in Sect. 4.2.3, this interesting phenomenon could explain why gender-based inequality in income has been quite large and remains large.

Overall, the post-revolution governments have had policies to develop rural areas, assist the poor and the marginalized population, and reduce inequality between urban and rural areas. Salehi-Isfahani (2009) shows that these policies led to reduction in absolute poverty, particularly in rural areas. Figure 7a replicates Salehi-Isfahani's results using the international absolute poverty line, compiled and utilized by the World Bank, of US\$1.90 in 2011 international dollars. As can be seen in Fig. 7a, b, absolute poverty substantially decreased in both rural and urban areas and for all ethnic groups. The poverty rates were close to zero by the late 2000 s.

\section{Data}

The two main datasets that are used in this study are: (1) Household Expenditure and Income surveys (HEIS) from 1990 through 2012, and (2) the 2006 census (available on IPUMS International). Sections 3.1 and 3.2 describe each of these datasets. Section 3.3

\footnotetext{
9 Note that those born after 1974 went to school for the first time after the revolution.

${ }^{10}$ For instance, women could not become agricultural engineers in the 1980s and early 1990s (Keddie 2000).

11 Many studies have been done on this issue. See for example Salehi-Isfahani (2005b), Chamlou and Karshenas (2016), Karshenas et al. (2016), Karshenas (2001), Moghadam (2000, 2011, 2013), Esfahani and Shajari (2012), Bahramitash and Esfahani (2011), Bahramitash and Olmsted (2014) and Majbouri (2010, 2015, 2016a, b, 2017).
} 
Fig. 6 Share of population participating in the labour force. Source: Authors' calculations based on Household Expenditure Surveys of 1990 through 2012. Women who work or are looking for work are considered participating in the labour force
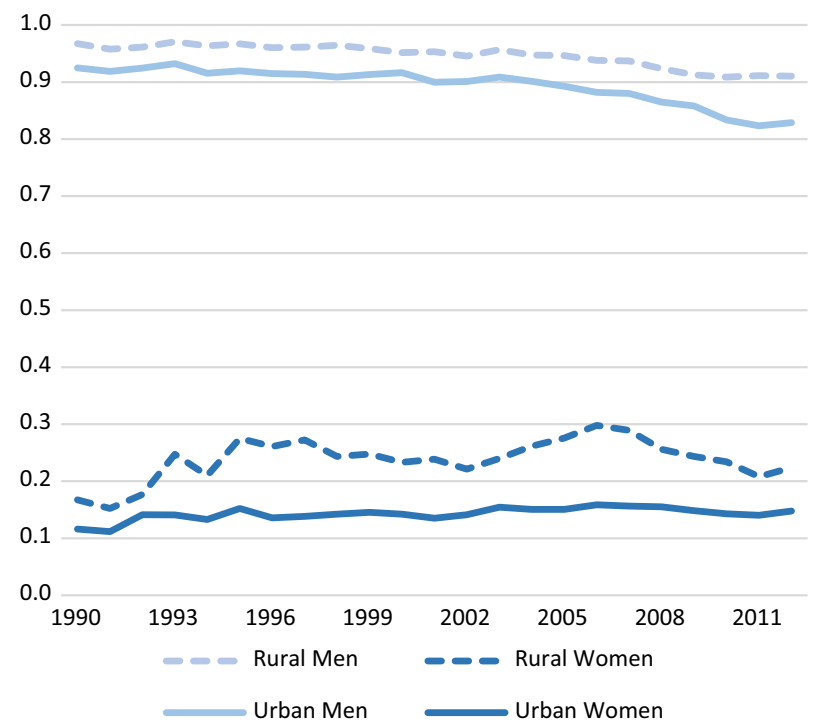
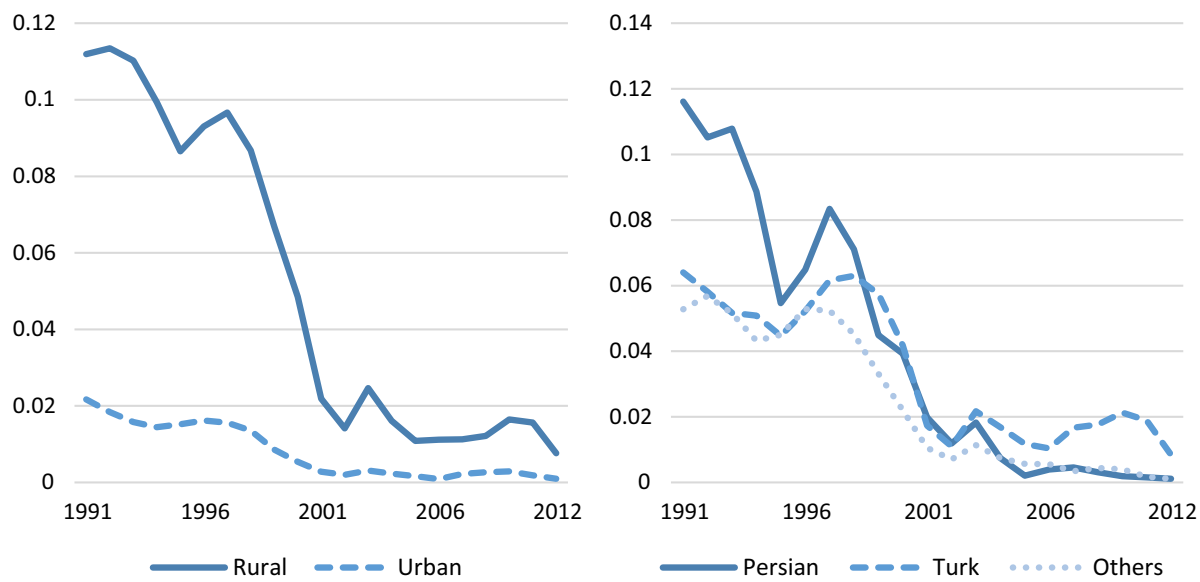

Fig. 7 Absolute poverty rates (share of population). a Across urban-rural, b across ethnicities. Source: Authors' calculations based on Household Expenditure Surveys of 1990 through 2012. The poverty line is $\$ 1.90$ in 2011 international dollars adopted by the World Bank

explains how various categorizations based on ethnicity, religion, and citizenship) were identified in the data.

\subsection{Household Expenditure and Income Surveys, 1990-2012}

The HEIS, available since 1984, are nationally representative surveys stratified at the urban and rural areas of each province. Only the surveys from 1990 through 2012 are used as full data for the years were available to us. Each year more than 19,000 (in some years up to 36,000 ) households are selected and data on basic demographics and very detailed disaggregated information on expenditures and incomes are collected. Demographics include, 
gender, age, education, marital status, employment status, and occupation. Expenditure information is collected at the household level, while income is at the individual level. Poverty measures can be found using expenditure per capita. Asset ownership dummies are also available in the data that can be used to calculate asset index. No information on ethnicity, ethnic language spoken by the individual, religion or nationality is collected.

\subsection{The 2006 Census}

The 2006 Census is a nationally representative 2\% sample of the census collected in 2006. It contains basic demographic information such as gender, age, education, and occupation, as well as religion, citizenship, and assets owned by the household. Assets are recorded with asset-ownership dummies. Using principal component method, one can calculate asset index which is highly predictive of income deciles in Iran. The religion and citizenship of individuals can be identified in the 2006 census, although it is not reported for all individuals. No information on income or expenditure is collected in this survey. ${ }^{12}$

\subsection{Ethnicity and Groups}

To study horizontal inequality, the first step is to define the groups. According to Stewart and Langer (2008), there are three conditions for categorizing people into groups. First, group membership is somewhat static, i.e. members are not able to change groups easily. Second, group membership is recognized not only by the person themselves and their group, but also by other members of the society. Third, group membership is meaningful to the individual, for example, it is an important factor to their identity. Group boundaries are mainly formed by ethnic groups. Ethnicity itself does not provide clear cut categorizing rule. Many factors are counted in the classifications of ethnic groups. For example Chandra (2004), Horowitz (1985), and Htun (2004) suggest skin colour, language, tribe, caste, religion, region, kinship, and other communal identity markers as grouping means.

Reviewing the Iranian history reveals that it 'has always been the host of diverse ethnic groups', as Amanolahi (2005) explains. Being on the Silk Road, it has been a crossroad for merchants, ideas, and migrants. Over time, eight major ethnic groups have settled in Iran. They are Persians, Azeris, Kurds, Lors, Arabs, Baluchs, Turkmans, and Mazanis, and Gilaks. As Amanolahi (2005) describes, biological factors are not the distinguishing features of these ethnicities. Each ethnicity has its own language and region of residence in Iran. Therefore, the region of residence, language, and cultural factors are the main defining features of ethnicity in Iran. ${ }^{13}$ In fact, like in some European countries, such as Belgium, Luxembourg, and Switzerland, language groups perfectly match ethnic groups. Therefore, in this study we use them interchangeably. Ethnicity is not a basis of social or economic rank in Iran. ${ }^{14}$

\footnotetext{
12 The 2011 census is also available but we did not include the results for that census as they were similar to the 2006 census and did not generate any value added for this analysis. Instead, we use Household Expenditure and Income Surveys which, as described, are significantly more comprehensive than censuses and cover 23 consecutive years. They offer a wealth of data that censuses do not.

13 Amanolahi (2005) focuses on ethnicity as a cultural phenomenon; one which 'encompasses the nonbiological aspect of man'.

14 Gisselquist (2013) argues that ethnic politics are different in societies in which ethnic groups are ranked versus unranked.
} 
Each ethnic group speaks not only their own language but also Persian. In fact, more than $90 \%$ of the country can speak and understand the language. ${ }^{15}$ It is the official language and has been the formal language, historically. ${ }^{16}$ Except Arabic, Armenian, and Azeri and Turkmani (two Turkic languages), other languages have the common root with Persian.

Those who only speak Persian are the majority of the population (over 50\%). Turkicspeaking Azeris are the second largest group. They have been a player in Iranian history since the 11th century and at times have ruled Iran. Particularly, they have been significantly influential in shaping the economic, social, and political landscape of Iran since the 1500s. ${ }^{17}$ Azeris mostly live in north and north-western Iran (east and west Azerbaijan, Ardebil, Zanjan, and Qazvin provinces.)

Kurds or Kurdish people are an old ethnic Iranian group living in western Iran, as well as in parts of Iraq, Turkey, and Syria. Many Kurds consider themselves descendants of Medes, one of the three main Iranian tribes (beside Persians and Parthians), who resided in Iran since 1000 BC. Kurds are mostly living in (north-)western provinces of Kurdistan, Kermanshah, and parts of the west Azerbaijan. But a small group of them have migrated to the Golestan and Khorasan provinces (in the north and north-east) as well. Most Kurds are Sunni Muslims.

Lors or Lurs speak Lurish language which is the closest to Archaic and Middle Persian (Coon 2005). They reside mostly in western Iran provinces and share borders with the Kurds in the west and north, Arabs in the south and Persians in the centre and the east. Arabs live mostly in southern provinces of Khuzestan and Hormozgan. Baluchs speak Baluchi, a western Iranian language (Elfenbein 1988), and live in south-east in Sistan and Baluchestan and practice Sunni Islam. Turkmans speak Turkmani (a Turkic language) and mostly live, along other ethnicities, in Golestan. Turkmans are also Sunni Muslims.

Ethnicity or the language an individual speaks is not asked in most data sets collected by the Statistical Centre of Iran, which is the only official organization in charge of collecting data in the country. These include the HEIS and Census datasets that we use in this study. Therefore, the only identifier of ethnicity is the region of residence of the household in these datasets. Region of residence is a good predictor of ethnicity, since each ethnic group has historically lived in particular regions. Although the borders of these regions are more fluid and mixing and intermarriage happens there, by and large, one can be confident that people living in a certain region belong to a certain ethnicity. In our datasets, we do not have the geolocation of the household. Therefore, we cannot identify the ethnicity of the

\footnotetext{
15 A vast amount of literature is in Persian and every ethnic group have more or less adopted the language. It has been spoken from Tajikistan and Uzbekistan in Central Asia to Afghanistan, and Iran; even in the Ottoman Empire, where Persian was the language of the court. It is not a surprise that Persian is and has been chosen as the formal language, even by Turkic origin Iranian governments.

16 Iran's constitution defined Persian as 'the official language and script of Iran' while recognizes the minorities' right to use their language. Article 15: The official language and script of Iran, the lingua franca of its people, is Persian. Official documents, correspondence, and texts, as well as text-books, must be in this language and script. However, the use of regional and tribal languages in the press and mass media, as well as for teaching of their literature in schools, is allowed in addition to Persian. Article 19: All people of Iran, whatever the ethnic group or tribe to which they belong, enjoy equal rights; and colour, race, language, and the like, do not bestow any privilege.

17 Safavid dynasty, originally from Azeri parts of Iran, created the first modern Iranian nation-state in 1501, and declared Shi'ite Islam as the state religion. It was a way of distinguishing itself from the Sunni dominated Ottoman empire. Isfahan, a major Persian city in central Iran, was selected as capital, and Persian was the formal language. Turkic origin Qajar dynasty, gained power in 1785, and chose the Persian city of Tehran as the capital. This trend is continued and now Azeris are well integrated into the economic and political system of Iran.
} 
household using the Geo-Referencing of Ethnic Groups (GREG) data ${ }^{18}$ that has the geo boundaries of ethnic groups (Weidmann et al. 2010). In the HEIS data sets, until 1998, only the province and urban-rural location of the household is observed. Therefore, the only predictor of location is the province and urban or rural place of the household. The provincial boundaries do not perfectly match the ethnic boundaries. Therefore, one cannot perfectly identify the ethnicity of the household using the data that we have. In other words, if one knows the province of residence of an individual, they cannot perfectly infer which of the eight ethnicities the individual belongs to. But, to minimize the inference error, we only define three ethnic groups: Persians (which include Shomalies), Azeris, and Others. It is possible to more accurately identify these three groups using the province of residence. Because Persians and Azeris together make more than $70 \%$ of the population, it makes sense to combine other smaller ethnic groups into one group. In a few instances that a province has mixed ethnicities (like the Tehran province), we take the ethnicity that is the majority ${ }^{19}$ (for example, Persians for Tehran). According to our categorization, the Persians, which include Shomalies (Mazanis and Gilakis), reside in Markazi, Gilan, Mazandaran, Fars, Kerman, Khorasane-e-Razavi, Isfahan, Hamedan, Bushehr, Semnan, Yazd, Tehran, Qom, North Khorasan, and South Khorasan.

There is only one set of data that can be used to infer ethnicity. Socio-economic Characteristics of the Household (SECH) surveys are nationally representative data sets that ask whether the individual can speak a second language (spoken in Iran). ${ }^{20}$ Using the SECH datasets for 1992 and 2001 and dividing the sample into three groups: Persians, Azeris, and Others (based on the second language the individual speaks) produces almost identical inequality measures as when we use province of residence to infer ethnicity (see Table 2). This further confirms that our method of identifying ethnicity using provinces is robust.

SECH is only available for 2 years (1992 and 2001), therefore, we cannot produce more results than what is reported in Table 2 with this dataset. But, as explained, HEIS is available for every year between 1990 and 2012. Therefore, we can estimate inequality measures for every year in this period and analyse the trend in these measures over time with precision. Thus, HEIS is the main source of data in this study.

In addition to ethnicity, we estimate inequality based on religion and nationality. ${ }^{21}$ The religion and citizenship of individuals can only be identified in the 2006 census, although it is not reported for all individuals. Tables 3 and 4 have the number of observations in each group in the 2006 census: As can be seen, the number of individuals in religions other than Islam is small. The same is true for citizenship. Therefore, we combine non-Muslims into

\footnotetext{
18 Accessible at https://icr.ethz.ch/data/greg/.

19 We use Iran's Cultural Council (2010) to identify the major ethnic group in each province.

${ }^{20} \mathrm{SECH}$ datasets are nationally representative panels. Three sets of SECH surveys were collected: 1987-1989, 1992-1995, and 2001-2003. Waves are collected annually. We had the last two panels and used them to compare results with those this study (see Table 2). Attrition is a major issue in these datasets as about $30 \%$ of the sample is lost by the third year of these surveys. Therefore, data for the first years of these panels, i.e. 1992 and 2001 are used.

21 There are multiple ethnic cleavages that are salient and might be studied in Iran. One we are unable to analyze in this paper is the Shi'a/Sunni distinction because we do not have any way to identify Shi'as and Sunnis. The religious sect is not collected in publically available data sets. Using regions to identify Shia's and Sunnis will lead to similar results as those found for ethnicity, because we used regions to identify ethnicities too. The ethnicities measured as "Others" are located in Sunni dominated areas. The two other ethnicities, Persians and Azeris, are Shi' as. Therefore, dividing the sample into Shi' as and Sunnis is like grouping Persians and Azeris into Shi' as and calling "Others" Sunnis. Hence, this seems to provide little value added on top of the analysis for ethnicities which is already offered.
} 
Table 2 Comparison of group-weighted inequality measures between SECH and HEIS over time. Source: Authors' calculations

\begin{tabular}{|c|c|c|c|c|c|c|}
\hline & \multicolumn{3}{|c|}{ SECH 1992 and HEIS 1992} & \multicolumn{3}{|c|}{ SECH 2001 and HEIS 2001} \\
\hline & GCOV & GGini & GTheil & GCOV & GGini & GTheil \\
\hline \multicolumn{7}{|c|}{ Education, people aged $15+$} \\
\hline SECH & 0.187 & 0.098 & 0.018 & 0.137 & 0.071 & 0.009 \\
\hline HEIS & 0.162 & 0.080 & 0.013 & 0.110 & 0.054 & 0.006 \\
\hline \multicolumn{7}{|c|}{ Education, people aged $25+$} \\
\hline SECH & 0.243 & 0.127 & 0.030 & 0.188 & 0.098 & 0.018 \\
\hline HEIS & 0.216 & 0.106 & 0.024 & 0.161 & 0.078 & 0.013 \\
\hline \multicolumn{7}{|c|}{ Asset Index } \\
\hline $\mathrm{SECH}$ & 0.110 & 0.058 & 0.006 & 0.085 & 0.042 & 0.004 \\
\hline HEIS & 0.160 & 0.078 & 0.013 & 0.088 & 0.042 & 0.004 \\
\hline \multicolumn{7}{|c|}{ Income, population aged $18+$} \\
\hline SECH & 0.141 & 0.071 & 0.010 & 0.195 & 0.099 & 0.020 \\
\hline HEIS & 0.180 & 0.090 & 0.017 & 0.216 & 0.109 & 0.025 \\
\hline \multicolumn{7}{|c|}{ Household per capita expenditure } \\
\hline SECH & 0.121 & 0.055 & 0.008 & 0.119 & 0.063 & 0.007 \\
\hline HEIS & 0.072 & 0.036 & 0.003 & 0.096 & 0.038 & 0.004 \\
\hline
\end{tabular}

Ethnic groups are found based on the second language that the individual speaks (in addition to Persian) in the SECH dataset. Ethnic groups are identified using province of residence in HEIS. Three ethnic groups were defined in each of these datasets: (1) Persian (including Shomalies), (2) Azeri, and (3) the others

one group and compare them with Muslims. We also combine all non-Iranians into one group and compare them with Iranians.

\section{Inequality Measures Over Time}

This section reports the results for the country-level measures of inequality from 1990 through 2012, using the HEIS surveys. First, the country-level measures are calculated and then the within-country measures across ethnic, gender, and regional groups are estimated.

\subsection{Country Level}

Fractionalization and polarization indices are very stable measures over time unless there is a large change in the share of population of one group versus another. ${ }^{22}$ The average fractionalization index measured over ethnic groups in the 1990-2012 period is 0.55 . It is about 0.568 in 1990 and declines slowly to 0.532 in 2012 (Fig. 13 in the "Appendix" reports this index over time.) This means there is practically no change in this measure over time.

\footnotetext{
${ }^{22}$ Fractionalization index is described in footnote \#3. Polarization index is defined based on Montalvo and Reynal-Querol (2005). It is $1-\sum_{i=1}^{n}\left(\frac{0.5-p_{i}}{0.5}\right)^{2} p_{i}$, in which $n$ is the number of groups and $p_{i}$ is the proportion of group $i$ in the population .
} 
Table 3 Number of observations across religion in the 2006 Census. Source: Authors' calculations

\begin{tabular}{lr} 
Muslim & $1,294,721$ \\
Christian: Assyrian or Chaldean & 879 \\
Christian: Armenian & 190 \\
Other Christians & 37 \\
Jewish & 61 \\
Zoroastrian & 214 \\
Other & 614 \\
\hline
\end{tabular}

Table 4 Number of observations across country of citizenship in the 2006 Census. Source: Authors' calculations

\begin{tabular}{lr}
\hline Iran & $1,265,685$ \\
Afghanistan & 19,218 \\
Other & 11,813 \\
\hline
\end{tabular}

The polarization index across ethnic groups in the 1990-2012 period has an average of 0.83 . It starts 0.846 in 1990 and slowly declines to 0.82 in 2012. In other words, there is little change, if any, in this measure over time (Fig. 13 in the "Appendix" reports this index over time.)

GINI coefficient for annual income at the country level is calculated over time and reported in Fig. 8. ${ }^{23}$

We are also interested in the inequality in the type of occupations various groups have. Occupations can be categorized according to skill level to high skill, medium skill, and low skill. Legislators, senior officials and managers, professionals, and technicians and associate professionals are considered high-skilled workers. Medium-skilled workers include clerks, service workers and shop and market salespeople, skilled agricultural and fishery workers, crafts and related trades workers, machine operators and assembly-line workers, and different ranks in the armed forces. Elementary occupations are considered low skilled. Since the number of categories for occupational skills is small (here, three), the variable that represent occupational skill will only take three values and will not be continuous. Therefore, measuring Group-weighted Coefficient of Variation (GCOV), Group-weighted Gini coefficient (GGINI), and Group-weighted Theil index (GTHEIL) may not be very informative. ${ }^{24}$ Instead, we measure cross-cuttingness and cross-fractionalization.

Cross-cuttingness and cross-fractionalization between gender and occupation are about 0.80 and 0.04 respectively. These measures between ethnicity and occupation are about 0.91 and 0.09 respectively. All these values are stable over time.

\footnotetext{
23 These measures are calculated using 'fastgini' command in Stata.

24 Frances Stewart's project on horizontal inequalities and conflict draws on these three measures of horizontal inequality: Group-weighted Coefficient of Variation (GCOV), Group-weighted Gini coefficient (GGINI), and Group-weighted Theil index (GTHEIL). In summary, these are extended versions of Coefficient of Variation, Gini coefficient, and Theil index that incorporate between group inequalities beyond the inequality in the population. Stewart et al. (2005) explore each of these measures in detail. The introduction to this special issue discusses these measures in more detail.
} 
Fig. 8 Gini coefficient for annual income. Source: Authors' calculations based on Household Expenditure Surveys of 1990 through 2012. The graph is the 2-year moving average of Gini coefficient for every year

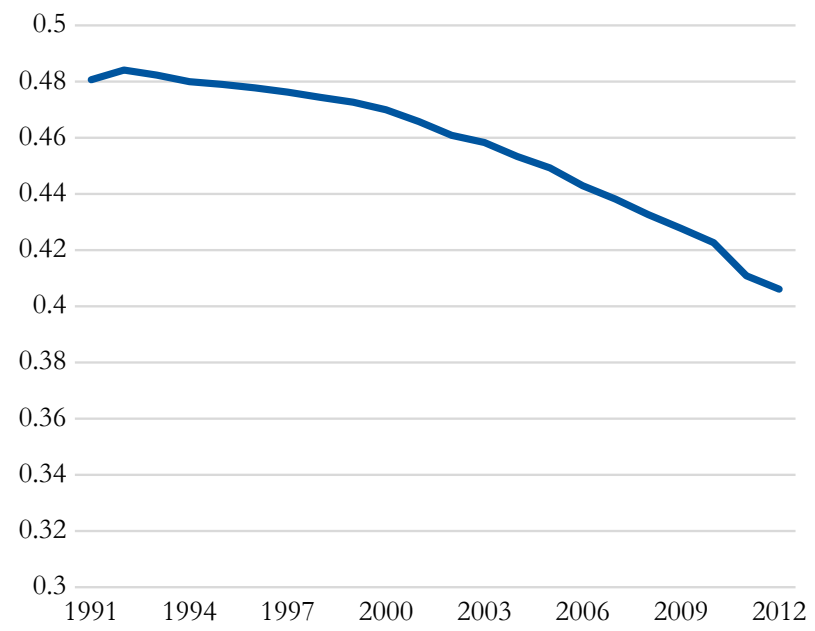

\subsection{Group-Based Inequalities Over Time}

\subsubsection{Education}

To be consistent with studies of other countries, two samples were used to measure inequality of education, the $25+$ and the $15+$ samples. It is almost imperative that everyone has completed their education by age 25 . If a lower age is chosen as a cut-off point (say 18), we do not know how many years of education a person who is a student may eventually achieve and therefore will under-estimate their education level. This underestimation is more likely to happen for highly educated and as a result we may underestimate inequality. On the other hand, there are many countries that experienced substantial increase in educational attainment in the last decades. Looking at the sample of age $25+$ is not able to depict such a change. Moreover, many drop out of school before age 15 and finalize their educational attainment. Therefore, the sample of $15+$ should be considered. Since the $15+$ sample is more relevant for Iran, the result for the $15+$ sample is reported here and the estimates for the 25+ sample are included in the "Appendix". Figure 9 reports the 2-year moving average of the estimates for group-based inequality in years of education attained across gender, ethnicity, urban/rural, and capital/others (Fig. 9a-d respectively.) As the capital is only identifiable in data after 1997, the results for group-based inequality measures between capital and the rest of the country are estimated for the years after 1997 (Fig. 9d).

Figure 9a depicts the inequality across men and women from 1990 through 2012. As can be seen, all inequality measures (GCOV, GGINI, and GTHEIL) between men and women have been continuously decreasing in this period. This interesting result is consistent with the literature on education in Iran. The increase in educational attainment, particularly for girls, has started decades ago. But after the Islamic Revolution of 1979, this rise in educational attainment was faster especially for girls for several reasons. One of the aims of the revolutionaries was to improve the conditions of the poor and people who were consistently on the margins for policy makers, particularly, people in rural areas and poor neighbourhoods of urban areas. In the decades after the revolution and even during the Iran-Iraq war in the 1980s, there has been significant investment in infrastructure of rural 
areas and small towns. Many projects in electrification, access to clean water, telephone and telecommunication, road building and, as mentioned, school and health facility construction were implemented. The result of these projects were significant expansion of infrastructure across the country which is shown in Table 1 and explained in Sect. 2. Especially, access to schools at all levels (primary, middle school, high school, as well as college and universities) substantially increased since the revolution. As a result, girls who are less likely to be sent to distant schools were now more likely to attend schools which were nearby.

Another development after the revolution was that all private schools became public. For example, the number of public primary schools rose by $60 \%$ the year after the revolution (Majbouri 2010). This means that there was a sudden rise in the supply of free education after the revolution. Girls' educational attainment is more responsive to price reductions, since demand for educating girls is more elastic than boys. This is because parents are more likely to take girls out of school than boys if the cost is high. As a result, after the revolution, parents sent their children, especially girls, to school more.

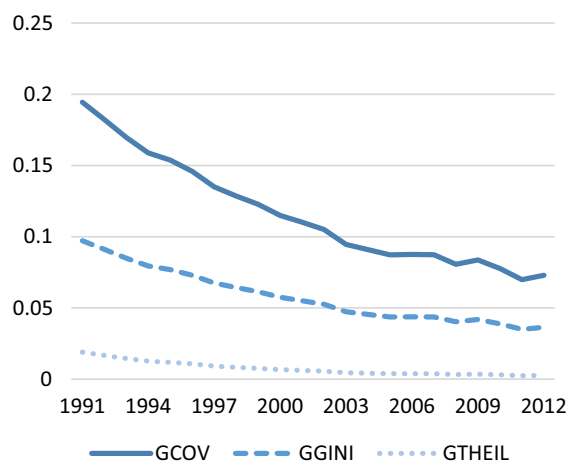

(a)

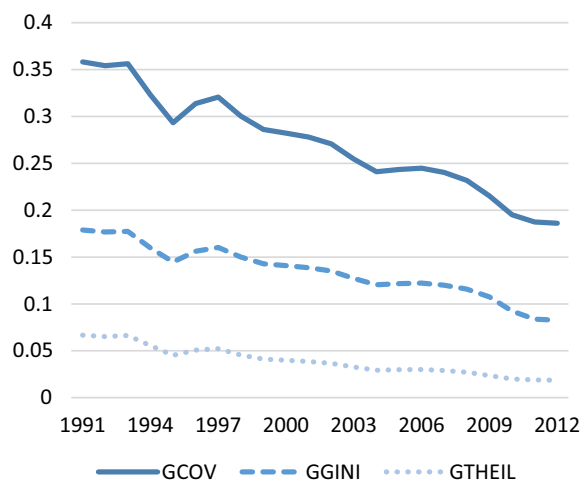

(c)

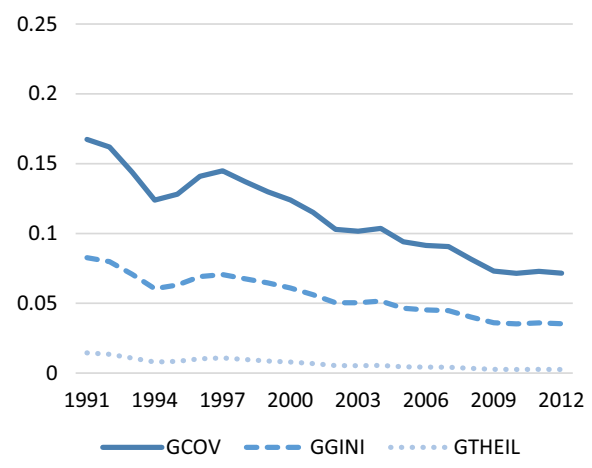

(b)

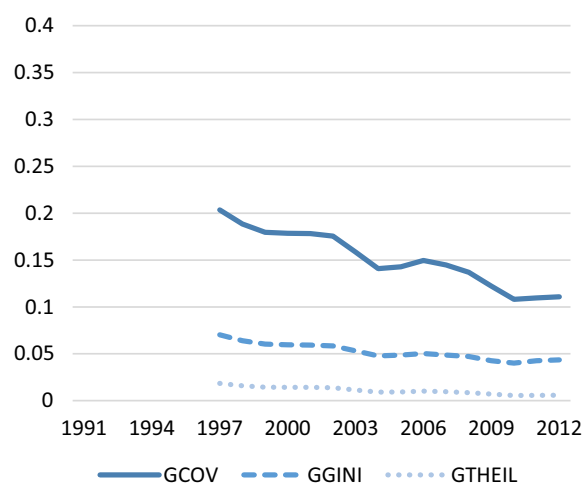

(d)

Fig. 9 Between-group inequality in educational attainment-years of education. a Gender, b ethnicity, c urban/rural, d capital/other. Note: Each figure depicts the 2-year moving average of Group-Based Coefficient of Variation (GCOV), Group-Based Gini (GGINI), and Group-Based Theil (GTHEIL) for years of education attained across various groups: male/female, ethnicity (Persian, Turk, Others), urban/rural, and capital city/others. The sample contains all individuals aged 15 and above. Data source: Household Expenditure and Income Surveys (HEIS) 
The third reason for the faster rise in female education compared to male is the gender based segregation of schools. Since schools were segregated after the revolution, conservative families were more likely to send their children to school as schools were considered 'safer' for their daughters (Majbouri 2010). The fourth reason is that the teachers' gender, particularly in middle and high schools, was supposed to be the same as the students'. Therefore, female teachers taught female students and male teachers taught male students. The quality of female teachers was higher than male teachers, on average. This was because, as we saw in Sect. 2, female labour force participation in Iran was (and still is) low (about 20\%), and there were only a few jobs, such as teaching, that were attractive to women for various reasons. ${ }^{25}$ Therefore, these jobs attract the top $20 \%$ of women who could work and wanted to. On the other hand, many jobs were available as well as attractive to men, and teaching was not necessarily one of their top choices. Therefore, the quality of female teachers was likely higher than the quality of male teachers. As a result, female students received higher quality education than male students and therefore, could attain more years of education than their male counterparts. All these explain the consistent decline in inequality of education across men and women between 1990 and 2012, as depicted in Fig. 9a. ${ }^{26}$

The general trends in group-based inequality measures in Fig. 9b-d are also downward. This means inequality across ethnicity, urban/rural and capital/others has been reduced since 1990. This reduction can be attributed to the continuous expansion of schooling infrastructure even at the tertiary level across the country. In 2012, all inequality measures across ethnic groups are at the same low level as inequality measures across gender. Regional inequalities (urban/rural and capital/others) have been almost halved in this period. Inequality among urban and rural areas is the largest compared to other categories and this is not surprising as return to education is different across rural and urban areas and individuals with the highest education migrate to urban areas. Therefore, rural areas will always have lower average education levels than urban areas not just because they have less access to education (especially tertiary level) but because of migration. As one can see the difference between the capital and the rest of the country has been always less than the difference between urban and rural areas, but at the end of 2012 the inequality between the capital and the rest of the country is still larger than inequality among ethnic groups and between genders.

Overall, one can argue that inequality in educational attainment has been on the decline across all groups and more opportunities are offered to people at the margin in the society. There is only a deviation from the trend in years 1992 through 1998 in Fig. 9b-d. Inequality decreased in 1992 through 1994, and then increased between 1995 and 1998. The potential reason behind the rise in inequality is the minor economic crisis of 1994 and 1995. The fast economic growth after the end of Iran-Iraq war and higher oil prices, encouraged the government to borrow more, mostly from international institutions and in the form of short-term debt. But the unexpected fall in oil prices in late 1993 made it very difficult to pay back these debts. This was because the share of short-term debt out of total public debt was larger in Iran compared to the countries affected in the East Asian currency

\footnotetext{
25 For example, according to law, husbands should agree with their wives working. Husbands are more likely to give permission to their wives to work when all of their wives colleagues are women. One of the jobs that offered (and still offers) such a working environment was teaching. All employees in girl's schools were female and hence female teachers had all-female colleagues.

${ }^{26}$ For more information on reasons behind the rise of female education in Iran see Keddie (2006) and Salehi-Isfahani (2005a: 286).
} 
crisis during 1997-98 (Pesaran 2000). As a result, the government, short in foreign currency, substantially increased the exchange rate, which raised the inflation to 50\% in 1995; an unprecedented rate (see Fig. 4). Higher prices reduced purchasing power, especially for the poor, and had impacts on households for a few years after this crisis. Since the people on the margin and the poor are more likely to reduce their educational attainment due to crisis, the inequality increased during the crisis.

\subsubsection{Assets}

We do not observe the value of assets the households have in the data. What we observe is whether the household owns a particular durable good or not. Examples of these durable goods are autos, motorcycles, bikes, and household appliances. Since we only have the binary information of whether the household owns a particular durable good or not, we can combine these binary data into one index using the principal component method for every year. We call this index, asset index, from now on.

Note that the principal component method gives us positive and negative values. But the inequality measures can be calculated on variables that take non-negative values (zero and above; such as income or expenditure). To turn the asset index into a non-negative variable without changing its distribution (i.e. inequality), we add the absolute value of the minimum of the index to it. The result is the asset index distribution shifted to the right by the size of the absolute value of its minimum. The minimum of this shifted distribution is zero and all values lay on or above zero, but the shape of the distribution and its dispersion does not change. Hence, inequality remains the same.

Since assets are recorded at the household level, it is not possible to estimate inequality measures between men and women. Therefore, inequality measures across ethnic groups, urban/rural, and capital/others are calculated. Figure 10 contains the results.

As can be seen, inequality in assets has been decreasing. For the results to be comparable and consistent, the basket of assets used to calculate the asset index has remained unchanged over time. In other words, when newer assets like computers, access to internet, and cell phones are reported in the surveys, they are not included in the basket of assets used to calculate the asset index. So the inequality measures shown in Fig. 10 are inequalities in the more basic assets. Therefore, the reason behind the downward trend in inequality measures is that every year more households owned these basic assets and hence, the difference among households were reduced every year. Interestingly, there is a similar increase in inequality between 1994 and 1998 as those reported for education. The potential explanation for this increase is the same: the economic crisis of 1994-95 which affected the marginalized population: the poor, and the rural population more.

Some of the assets used to create asset index are public goods, such as access to electricity and clean water. The decreasing trend in inequality between ethnic groups supports the argument by Gisselquist (2014) that ethnic diversity by itself does not 'lead to poor provision of public goods.'

\subsubsection{Income}

In this section, we calculate the inequality measures for income at the individual level. All sources of income including wages and salaries, business profits, pensions, revenue from 


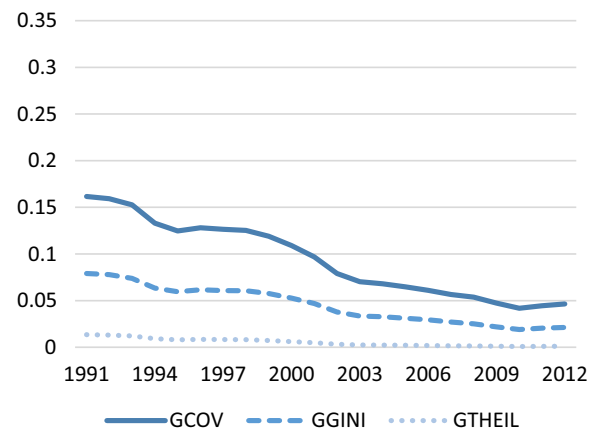

(a)

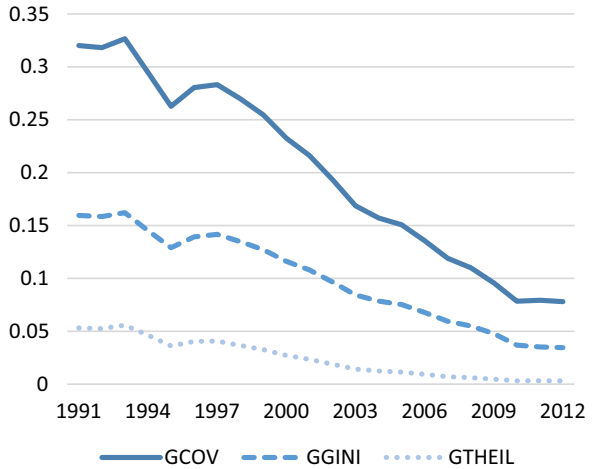

(b)

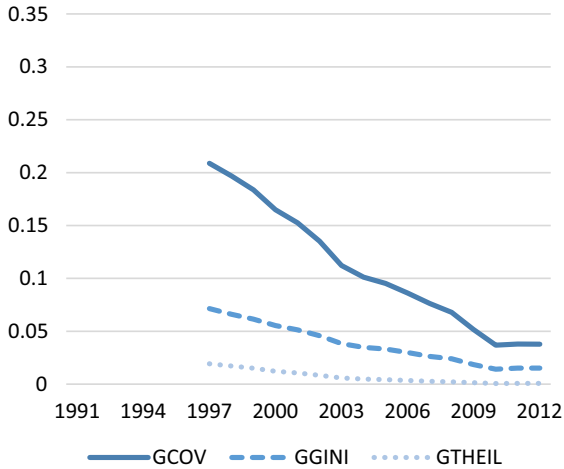

(c)

Fig. 10 Inequality in assets - asset index. a Ethnicity, b urban/rural, c capital/other. Note: Each figure depicts the 2-year moving average of Group-Based Coefficient of Variation (GCOV), Group-Based Gini (GGINI), and Group-Based Theil (GTHEIL) for years of education attained across various groups: ethnicity (Persian, Turk, Others), urban/rural, and capital city/others. The sample contains all individuals aged 15 and above. Data source: Household Expenditure and Income Surveys (HEIS)

renting properties and assets, educational and charity grants are added up at the individual level. All incomes are annual. ${ }^{27}$ Figure 11 reports the results.

We use two samples to study inequality of income between men and women. One is a sample of all men and women who earned income and the other consists of all men and women above age 25, regardless of whether they earned income or not. This is because female participation in the labour market was (and still is) low in Iran (around 20\%) and not all working women earned income (some were unpaid family labour working in the family business without pay). Therefore, income for the majority of women was zero. This zero female income as opposed to the positive male income creates an unequal bargaining power within the household for women and affects household decisions. Therefore, any inequality measure that ignores women who do not work is ignoring this inequality and

27 Since sometimes business profits are negative, income can be a negative variable. But only a very small fraction of the sample has negative incomes (around 1\%). Those negative incomes are replaced with zero in the sample so that the measures are correctly correlated. 
underestimates the inequality between genders. On the other hand, one may argue that some women do not work by their own choice and including their zero income in compiling inequality measures gives us an over-estimation of inequality. Here, we report the results including and excluding women with no income. Figure 11a reports inequality measures among men and women who earn income and Fig. 11b depicts them among all men and women who are 18 or older regardless of whether they work or not. ${ }^{28}$

We learn three lessons from the results: first, as expected, inequality is substantially larger in the sample that includes women without income (compare Fig. 11a with b). The measures reported in Fig. 11b are the largest group-based measures of inequality reported in this study. The second lesson is that inequality of income between male and female earners slowly increased in the 1990s as the economy experienced a downturn from the 1994-95 crisis and the bust in the oil markets. But in the 2000s, with the significant increase in oil prices, inequality of gender decreased over time (Fig. 11a). Figure 11b, also shows some reduction in inequality among all men and women between 1990 and 2012. This can be attributed to two factors: (1) boom in the oil markets, and (2) a small rise in the share of women who worked for pay during this period, and hence a reduction in the share of women with no income (see Fig. 6). Inequality across ethnic groups was fluctuating but roughly stable in the 1990-2012 period (Fig. 11c), but it is substantially smaller than inequality between genders. This means that gender inequality is more important than ethnic inequality in this context. The trend in ethnic inequality of income roughly follows the rise and fall of the oil market. When oil markets boom inequality improves. Figure $11 \mathrm{~d}$, e show inequality across regions. Not surprisingly, inequality between urban and rural areas is larger than inequality between the capital and the rest of the country. They generally have a decreasing trend over time, except a sharp increase in inequality in 2008 and 2009. One reason which could have affected on this was that 2007 through 2009 were drought years in Iran, which could have particularly affected the inequality between urban and rural areas negatively.

\subsubsection{Expenditure Per Capita}

Total expenditure for the household is calculated based on consumption of durable and non- durable goods and services in 1 month. HEIS datasets provide a very disaggregated and detailed account of all types of expenditure at the household level. Expenditure on non-durable goods, such as food and clothing, is measured in the month prior to each survey. But the expenditure on durable goods is measured in the 12 months prior to the survey. Therefore, this expenditure is divided by 12 to get the monthly average. At the end, the total expenditure for the household is divided by the size of the household to get per capita expenditure in the household.

Since the expenditure for men and women is not distinguishable, we cannot estimate inequality between genders, but inequality across other groups can be calculated. Figure 12 shows these inequality measures over time.

The measures of inequality between ethnicities seem to be following the oil prices/oil revenue per capita. When the oil prices dipped in 1994 and the economy went into recession, inequality started to rise. It remained high until 2002 when oil prices started to rebound. With the rise of oil prices between 2003 and 2008, ethnic inequality declined. Due to the collapse of oil prices in 2011, there are signs of rise in inequality.

$\overline{28}$ Samples used in all sub-figures include people aged 18 and above. 


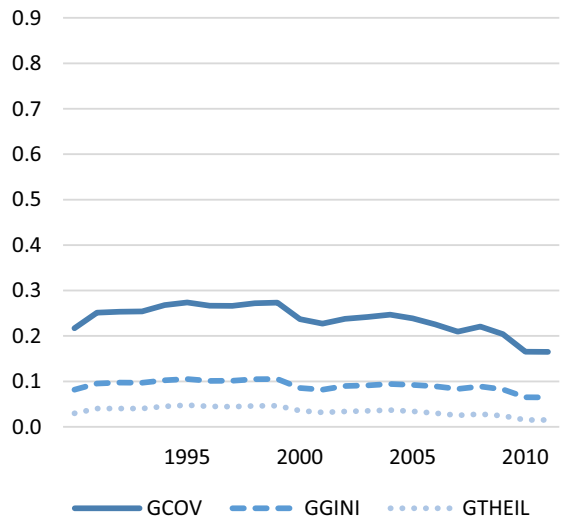

(a)

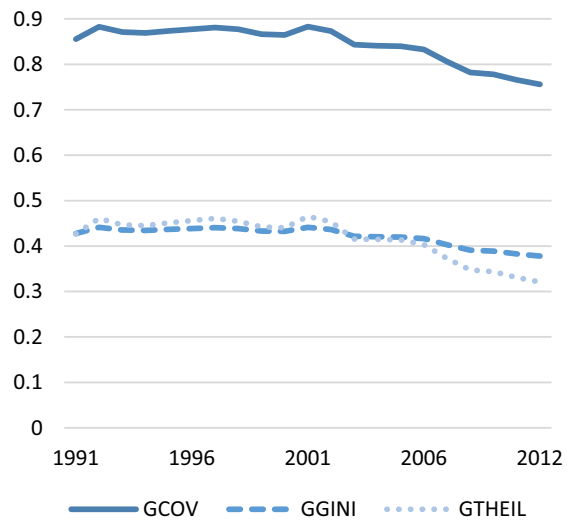

(b)

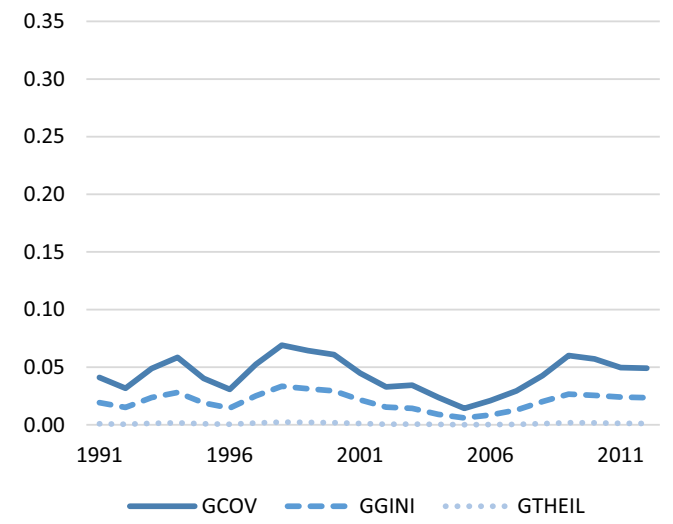

(c)

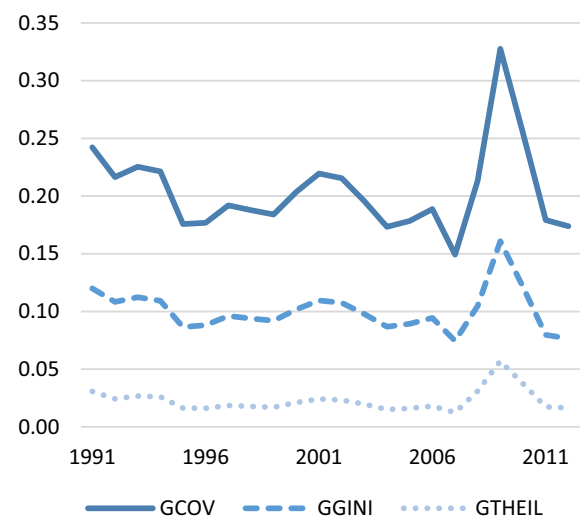

(d)

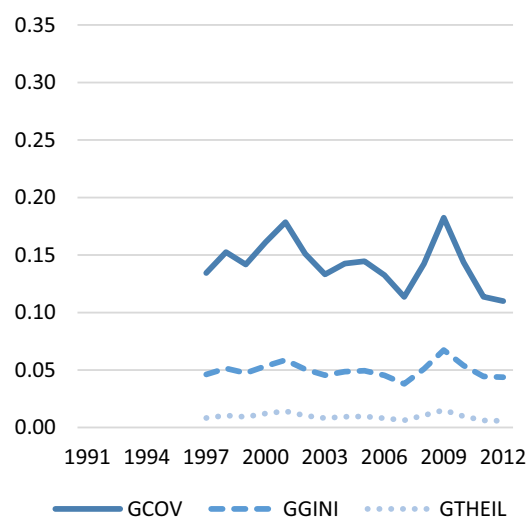

(e) 
4Fig. 11 Inequality in income for people aged 18+. a Gender-women and men who earned income, b gender-all women and men, c ethnicity, d urban/rural, e capital/other. Note: Each figure depicts the 2-year moving average of Group-Based Coefficient of Variation (GCOV), Group-Based Gini (GGINI), and Group-Based Theil (GTHEIL) for individual level income across various groups: male/female, ethnicity (Persian, Turk, Others), urban/rural, and capital city/others. The sample contains all individuals aged 18 and above who earned income (except for b). Data source: Household Expenditure and Income Surveys (HEIS)

The inequality between urban and rural areas and between capital and the rest of the country seem to roughly follow the oil markets as well. As the oil markets boom, inequality declines. inequality between the capital and the rest of the country dropped significantly since 2002. This could be due to the rise in cost of living in all urban areas across the country during the 2000s. The capital city is already at full capacity and other cities are becoming more attractive than the capital. This has raised the cost of living and housing in those cities and raised per capita expenditure reducing the inequality between the capital and other cities in the country. More research is required to clearly understand the changes in inequality of expenditure between the capital and the rest of the country.

\section{Inequality Measures Based on the 2006 Census}

\subsection{Country Level}

This section reports the results of the country-level measures of inequality in 2006. This is the only dataset which includes religion and citizenship for each individual. Therefore, we use it to estimate between group inequality for religious and citizenship groups. First, polarization and fractionalization indices for these groups at the country level are calculated and then the between-group inequality measures are reported. Using the Census data, it is also possible to estimate these indices and measures for ethnicity and gender dimensions in 2006. But, we do not report them here, since they are the same as the estimates using the HEIS data for 2006 that we have already reported in Sect. 4.

As can be seen from Table 5, Iran is very homogeneous in terms of religion and citizenship, because the polarization and fractionalization indices are small. This is because about $99 \%$ of the population have the same religion, Islam, and 90-95\% are Shi'ite. In terms of citizenship, although the variable of citizenship has missing values as some noncitizens may prefer not to report their actual citizenship, ${ }^{29}$ we expect that polarization and fractionalization indices to be small. This is because according to the largest estimates, only about $2-4 \%$ of the population have foreign citizenship.

\subsection{Inequalities Across Religion and Citizenship}

Three measures of Group-weighted Coefficient of Variation (GCOV), Group-weighted Gini coefficient (GGINI), and Group-weighted Theil index (GTHEIL) are calculated based on gender, ethnicity, religion, and nationality.

${ }^{29}$ For example, in fear of deportation. 


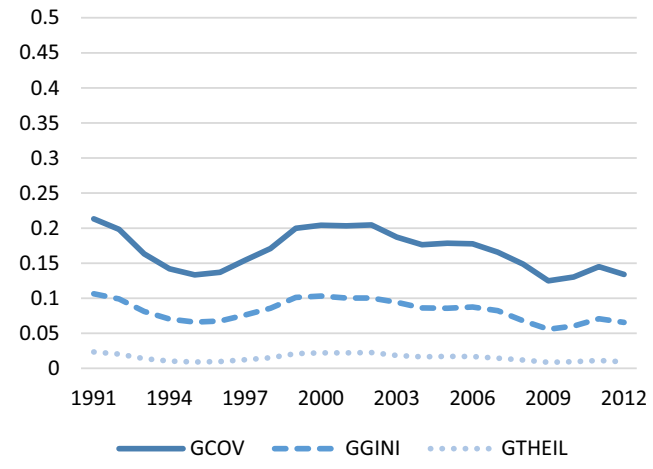

(a)

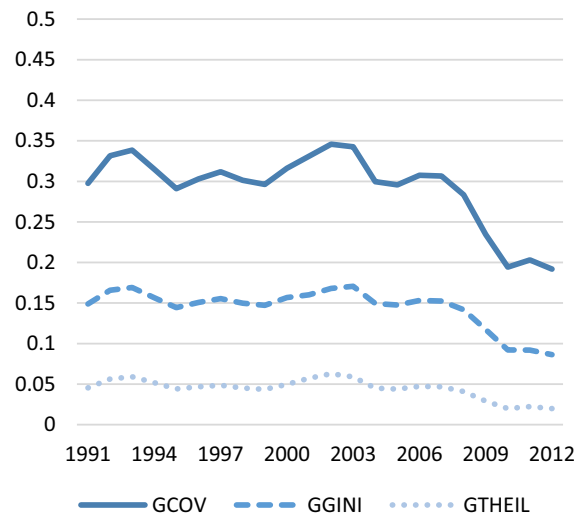

(b)

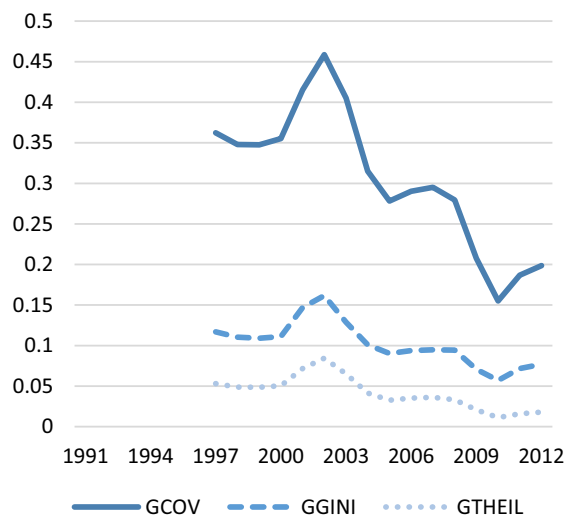

(c)

Fig. 12 Inequality in per capita expenditure. a Ethnicity, b urban/rural, c capital/other. Note: Each figure depicts the 2-year moving average of Group-Based Coefficient of Variation (GCOV), Group-Based Gini (GGINI), and Group-Based Theil (GTHEIL) for per capita expenditure across various groups: ethnicity (Persian, Turk, Others), urban/rural, and capital city/others. The sample contains all individuals aged 15 and above Data source: Household Expenditure and Income Surveys (HEIS)

Table 5 Polarization and fractionalization. Source: Authors' calculations

\begin{tabular}{lll}
\hline & Polarization & Fractionalization \\
\hline Citizenship & 0.115 & 0.057 \\
Religion & 0.017 & 0.008 \\
\hline
\end{tabular}

\subsubsection{Education}

As discussed in Sect. 4.2.1, two samples were used to measure inequality of education, the $25+$ and the $15+$ samples. Table 6 reports the results across citizenship and religion.

As depicted, between-group inequalities across both citizenship and religious groups are small and almost identical in both samples. The results show that there is no horizontal 
Table 6 Between-group inequality measures for average years of education attained. Source: Authors' calculations

\begin{tabular}{llllll}
\hline & $15+$ sample & & & $25+$ sample & \\
\cline { 2 - 3 } \cline { 5 - 6 } & Citizenship & Religion & & Citizenship & Religion \\
\hline GCOV & 0.055 & 0.004 & & 0.052 & 0.008 \\
GGINI & 0.009 & 0.0003 & & 0.008 & 0.001 \\
GTHEIL & 0.002 & 0.00001 & 0.002 & 0.00003 \\
\hline
\end{tabular}

inequality on these dimensions, particularly when it comes to religion. Religious minorities are often at least as educated (if not more-educated) as Muslims (Table 7).

Similar to education, inequality is very low and almost non-existent between citizens and non-citizens.

\subsubsection{Occupation}

In this section, we study inequality in the job market. We are interested in the inequality in type of occupations various groups have. As discussed in Sect. 4.1, since the variable that represents occupational skill will only take three values, measuring GCOV, GGINI, and GTHEIL may not be very informative. Instead, we measure cross-cuttingness and crossfractionalization between occupation on one hand, and religion, citizenship, and gender on the other. Table 8 reports the result.

Interestingly, the high cross-cuttingness values show that there is a lot of overlap between the three occupational skills and religion and citizenship groups. This means that there is almost equality among groups in these dimensions. The overlap is less between men and women, but still substantial.

According to Census of 2006 , less than $13 \%$ of all workers above age 18 are women. Going one step further and examining the jobs that are performed by men and women, one observes that more than $30 \%$ of high skilled workers are women (Table 9). This is while only $5.8 \%$ of low-skilled workers are women (compared to $94.2 \%$ for men). This means that most women are concentrated in higher skilled occupations. ${ }^{30}$

\section{Conclusion}

Our study of the group-based inequalities in Iran presents encouraging results: poverty and inequality are generally decreasing, and access to public goods (piped water, electricity, and piped gas) are increasing. Our results suggest that Iran is an example of sustainable progress in decreasing poverty and inequality. Iran's experience is particularly important as sustainable progress continued despite the war, several rounds of sanctions, and low price of oil. The substantial reduction in between-group inequalities in Iran has lessons for other developing countries. Expansion of educational and health infrastructure in Iran, particularly to rural areas and to the marginalized population, has reduced between-group

\footnotetext{
30 In our 2\% census sample, there are 23,309 women in high skilled jobs. These the high skilled women are most frequently reported as managers (514 women), scientists and engineers (782 women), doctors and surgeons (499 women), pharmacists (52 women), professors (651 women), accountants and financial experts (1182 women), school principals (1062 women), college educated teachers and educators (9456 women), college educated nurses (1507 women), lawyers (152 women), paralegals (180 women), other college graduated professionals (1500 women), technicians (2444 women), and Clerks (2239 women).
} 
Table 7 Between-group inequality measures for asset index. Source: Authors' calculations

\begin{tabular}{llr}
\hline & Citizenship & Religion \\
\hline GCOV & 0.008 & 0.001 \\
GGINI & 0.001 & 0.00005 \\
GTHEIL & 0.00003 & 0.000001 \\
\hline
\end{tabular}

Table 8 Cross-cuttingness and cross-fractionalization between the occupational skill levels and religion, citizenship, as well as gender-the 2006 Census. Source: Authors' calculations

\begin{tabular}{llll}
\hline & Religion & Citizenship & Gender \\
\hline Cross-cuttingness & 0.990 & 0.927 & 0.767 \\
Cross-fractionalization & 0.580 & 0.572 & 0.461 \\
\hline
\end{tabular}

Table 9 Percentage of women and men in various occupational skill levels, the 2006 Census. Source: Authors' calculations

\begin{tabular}{lllll}
\hline & High skilled & Medium skilled & Low skilled & Total \\
\hline Men & 69.6 & 89.7 & 94.2 & 87.1 \\
Women & 30.4 & 10.3 & 5.8 & 12.9 \\
Total & 100 & 100 & 100 & 100 \\
\hline
\end{tabular}

inequalities. The social policies have improved wellbeing and living standard for the poor and the rural population, and reduced inequality. Hence, rural development should be recognized as a powerful multi-dimensional factor in development policy.

There are significant reductions in inequality of education as well as assets among various groups. At the same time, some reduction in between-group inequalities in per capita expenditure and income are observed in the 1990-2012 period. Income and expenditure inequalities between some groups seem to have an opposite relationship with the trend in oil prices and revenues. But it is hard to infer any clear causal path without further analysis and research. There are several suggestions for future research. First, further research is required to more carefully investigate the relation between ups and down of the oil price and individuals wellbeing. Second, extending this analysis to similar countries, other oil producing countries or other MENA countries, and providing between countries comparison. Third, while the gender gap in education declined significantly, female participation in the labour market remains low. Middle East scholars have made a series of policy recommendations to increase the FLFP. One is to improve the social acceptance of women working outside home (instead of the stay-home wife norm) through change in social and economic infrastructure (Karshenas 2001; Hayo and Caris 2013; Karshenas et al. 2016). Other recommendations include enforcing gender-neutral policy in the work place (Karshenas 2001; Hayo and Caris 2013; Karshenas et al. 2016), giving tax incentives to firms who employ considerable number of women workers (Karshenas 2001), provision of child care and maternity leave (Karshenas 2001), and change in the family laws to support this social change (Majbouri 2017). Women with tertiary education are 
more active in private sector and as entrepreneurs. Reforming the financial system to enhance availability of credit to women, especially to self-employed and entrepreneurs, not only improves the FLFP but also creates more jobs in the economy (Esfahani and Shajari 2012; Karshenas et al. 2016). These policies reduce gender inequality in the economy and enhance the living standards of future generations.

Acknowledgements This research was supported by United Nations University World Institute for Development Economics Research (UNU-WIDER) as part of the 'Disadvantaged Groups and Social Mobility' project. We are thankful to Dr. Rachel Gisselquist and Dr. Carla Canelas who provided expertise and valuable advice that greatly assisted the research. We are also grateful to the editor in chief, Prof. Filomena Maggino, the anonymous referee, and our colleagues in UNU-WIDER workshop for insightful comments. Specially, we have to express our appreciation to Dr. Ivan Gachet for sharing his code with us. The funding for this research was generously provided by the United Nations University -WIDER project on 'The politics of group-based inequalities - measurement, implications, and possibilities for change' which is part of a larger research project on "Disadvantaged Groups and Social Mobility." All remaining errors are ours.

Open Access This book is licensed under the terms of the Creative Commons Attribution-NonCommercial-ShareAlike 3.0 IGO License (https://creativecommons.org/licenses/by-nc-sa/3.0/igo/), which permits any noncommercial use, sharing, adaptation, distribution, and reproduction in any medium or format, as long as you give appropriate credit to the UNU-WIDER, provide a link to the Creative Commons licence and indicate if changes were made. If you remix, transform, or build upon this book or a part thereof, you must distribute your contributions under the same licence as the original.

\section{Appendix}

See Fig. 13.

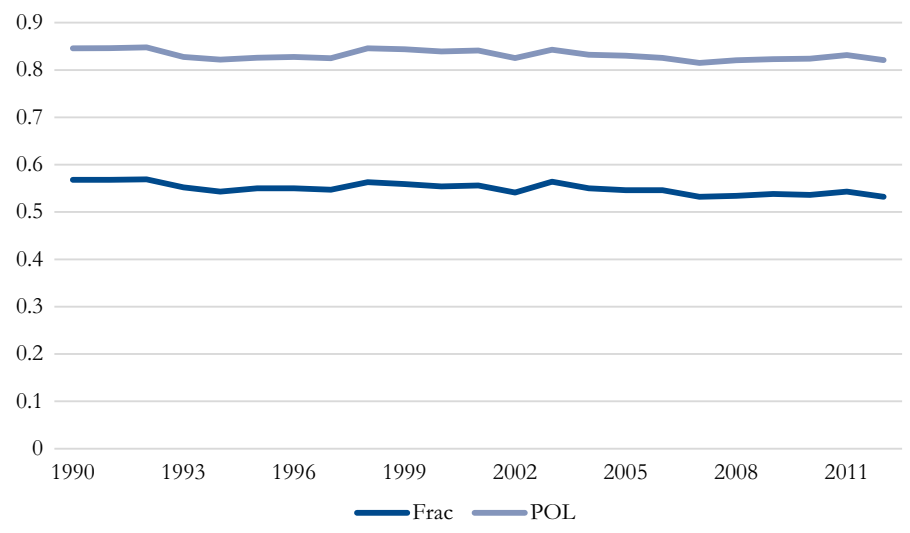

Fig. 13 Fractionalization and polarization. Data source: Household Expenditure and Income Surveys (HEIS)

\section{References}

Abbasi-Shavazi, M. J., McDonald, P., \& Hosseini-Chavoshi, M. (2009). The Fertility transition in Iran: Revolution and reproduction. New York: Springer. 
Aghajanian, A. (1983). Ethnic inequality in Iran: An overview. International Journal of Middle East Studies, 15(2), 211-224.

Alesina, A., Devleeschauwer, A., Easterly, W., Kurlat, S., \& Wacziarg, R. (2003). Fractionalization. Journal of Economic growth, 8(2), 155-194.

Amanolahi, S. (2005). A note on ethnicity and ethnic groups in Iran. Iran \& the Caucasus, 9(1), 37-41.

Assadzadeh, A., \& Paul, S. (2004). Poverty, growth, and redistribution: A study of Iran. Review of Development Economics, 8(4), 640-653.

Bahramitash, R., \& Esfahani, H. S. (Eds.). (2011). Veiled employment: Islamism and the political economy of women's employment in Iran. Syracuse, NY: Syracuse University Press.

Bahramitash, R., \& Olmsted, J. C. (2014). Choice and constraint in aid work: Women from low-income households in Tehran. Feminist Economics, 20(4), 260-280.

Central Intelligence Agency (CIA). (2013). The world factbook 2012-13. Washington, DC: CIA.

Chamlou, N., \& Karshenas, M. (Eds.). (2016). Women, work and welfare in the Middle East and North Africa: The role of socio-demographics, entrepreneurship and public policies. London: Imprerial College Press.

Chandra, K. (2004). Why ethnic parties succeed: Patronage and ethnic head counts in India. New York: Cambridge University Press.

Coon, C. S. (2005). Iran: Demography and ethnography. In E. van Donzel, B. Lewis and Ch. Pellat, Assisted by C. Dumont, G. R. Hawting and M. Paterson (eds.), Encyclopaedia of Islam (Vol 4, pp. 10-18). Leiden: E. J. Brill.

Elfenbein, J. (1988). BALUCHISTAN iii. Baluchi language and literature. Encyclopedia Iranica. http:// www.iranicaonline.org/articles/baluchistan-iii. Accessed December 30, 2014.

Esfahani, H. S., \& Shajari, P. (2012). Gender, education, family structure, and the allocation of labor in Iran. Middle East Development Journal, 4(2), 1-40.

Fearon, J. D. (2003). Ethnic and cultural diversity by country. Journal of Economic Growth, 8(2), 195-222.

Gisselquist, R. M. (2013). Ethnic politics in ranked and unranked systems: An exploratory analysis. $\mathrm{Na}$ tionalism and Ethnic Politics, 19(4), 381-402.

Gisselquist, R. M. (2014). Ethnic divisions and public good provision, revisited. Ethnic and Racial Studies, 37(9), 1605-1627.

Hakimian, H. (2014). Institutional change, policy challenges and macroeconomic performance: 1979-2004. In Parvin Alizadeh \& Hassan Hakimian (Eds.), Iran and the global economy: Petro populism, Islam and economic sanctions (pp. 46-75). London: Routledge.

Hayo, Bernd, \& Caris, Tobias. (2013). Female labour force participation in the MENA region: The role of identity. Review of Middle East Economics and Finance, 9(3), 271-292.

Horowitz, D. L. (1985). Ethnic groups in conflict. Oakland, CA: University of California Press.

Htun, M. (2004). Is gender like ethnicity? The political representation of identity groups. Perspectives on Politics, 2(3), 439-458.

Iran's Council of Culture. (2010). Tarh-e Barresi va Sanjesh-e Shakheshay-e Farhang-e Omoony-e Keshvar. In Persian: Survey and evaluation of cultural indices in Iran. Tehran: Nashr Publications.

Jayaraj, D., \& Subramanian, S. (2006). Horizontal and vertical inequality: Some interconnections and indicators. Social Indicators Research, 75(1), 123-139.

Karshenas, M. (2001). Economic liberalization, competitiveness, and women's employment in the Middle East and North Africa. In D. Salehi-Isfahani (Ed.), Labour and human capital in the Middle East (pp. 92-147). Reading: Ithaca Press.

Karshenas, M., Moghadam, V. M., \& Chamlou, N. (2016). Women, work and welfare in the Middle East and North African: Introduction and overview. In Nadereh Chamlou \& Massoud Karshenas (Eds.), Women, work and welfare in the Middle East and North Africa: The role of socio-demographics, entrepreneurship and public policies (pp. 1-29). London: Imperial College Press.

Keddie, N. R. (2000). Women in Iran since 1979. Social Research, 67(2), 405-438.

Keddie, N. R. (2006). Modern Iran: Roots and results of the revolution. New Haven, CT: Yale University Press.

Majbouri, M. (2010). Against the Wind: Labor force participation of women in Iran. Ph.D. thesis. Los Angeles: University of Southern California.

Majbouri, M. (2015). Female labor force participation in Iran: A structural analysis. Review of Middle East Economics and Finance, 11(1), 1-24.

Majbouri, M. (2016a). Against the wind: Women's labor force participation and economic instability in Iran. Feminist Economics, 22(4), 31-53.

Majbouri, M. (2016b). Twins, family size, and female labor force participation in Iran. Economic Research Forum Working Paper Series 1046. Giza: ERF. http://erf.org.eg/publications/twins-family-size-andfemale-labor-force-participation-in-iran/. Accessed 22 Nov 2017. 
Majbouri, M. (2017). Oil, laws, and female labor force participation. International Advances in Economic Research, 23(1), 91-106.

Moghadam, V. M. (2000). The state and the social position of women. In P. Alizadeh (Ed.), The economy of Iran: The dilemmas of an Islamic state. London: I.B. Tauris.

Moghadam, V. M. (2011). Feminism and family law in Iran: The struggle for women's economic citizenship in the Islamic Republic. In Fatima Sadiqi \& Moha Ennaji (Eds.), Women in the Middle East and North Africa: Agents of change (pp. 114-128). London and NY: Routledge.

Moghadam, V. M. (2013). Modernizing women: Gender and social change in the Middle East. Boulder, CO: Lynne Rienner Publishers. Revised third edition. First published in 1993.

Montalvo, J., \& Reynal-Querol, M. (2005). Ethnic polarization, potential conflict, and civil wars. American Economic Review, 95(3), 796-816.

Pesaran, M. H. (2000). Economic trends and macroeconomic policies in post-revolutionary Iran. In P. Alizadeh (Ed.), The economy of Iran: The dilemmas of an Islamic State (pp. 63-100). London: I.B. Tauris.

Salehi-Isfahani, D. (2005a). Human resources in Iran: Potentials and challenges. Iranian Studies, 38(1), $117-147$.

Salehi-Isfahani, D. (2005b). Labor Force Participation of Women in Iran: 1987-2001. Manuscript.

Salehi-Isfahani, D. (2009). Poverty, inequality, and populist politics in Iran. Journal of Economic Inequality, 7(1), 5-28.

Salehi-Isfahani, D., Abbasi-Shavazi, M. J., \& Hosseini-Chavoshi, M. (2010). Family planning and rural fertility decline in Iran: The impact of rural health clinics. Health Economics, 19(1), 159-180.

Salehi-Isfahani, D., Belhaj Hassine, N., \& Assaad, R. (2014). Equality of opportunity in educational achievement in the Middle East and North Africa. The Journal of Economic Inequality, 12(4), 489-515.

Salehi-Isfahani, D., \& Majbouri, M. (2013). Mobility and poverty dynamics in Iran: Evidence from the 1992-1995 panel survey. The Quarterly Review of Economics and Finance, 53(3), 257-267.

Stewart, F. (2000). The root causes of humanitarian emergencies. In E. W. Nafziger, F. Stewart, \& R. Väyrynen (Eds.), War, hunger and displacement: The origins of humanitarian emergencies (Vol. 1, pp. 1-43). Oxford: Oxford University Press.

Stewart, F. (2005). Horizontal inequalities: A neglected dimension of development. In UNU-WIDER (Ed.), Wider perspectives on global development (pp. 101-135). London: Palgrave Macmillan.

Stewart, F., Brown, G. K., \& Mancini, L. (2005). Why horizontal inequalities matter: Some implications for measurement. Oxford: Centre for Research on Inequality, Human Security and Ethnicity (CRISE).

Stewart, F., \& Langer, A. (2008). Horizontal inequalities: Explaining persistence and change. In F. Stewart (Ed.), Horizontal inequalities and conflict: Understanding group violence in multiethnic societies (pp. 54-82). London: Palgrave Macmillan.

van Staveren, I., \& Pervaiz, Z. (2017). Is it ethnic fractionalization or social exclusion, which affects social cohesion? Social Indicators Research, 130(2), 711-731.

Weidmann, N. B., Ketil Rød, J., \& Cederman, L.-E. (2010). Representing ethnic groups in space: A new dataset. Journal of Peace Research, 47(4), 491-499. 